\title{
Numerical research on thermal performance of water-flow window as hospital curtain-wall
}

\author{
Chunying $\mathrm{Li}^{1}$, Haida Tang ${ }^{1}$, Jianhua Ding ${ }^{1, *}$ and Yuanli Lyu ${ }^{2}$ \\ ${ }^{1}$ School of Architecture \& Urban Planning/BenYuan Design and Research Center, Shenzhen University, Shenzhen, China \\ ${ }^{2}$ Department of civil architecture and environment, Xihua University, China
}

\begin{abstract}
Water-flow window can reduce indoor cooling load from direct solar radiation and preheat domestic hot water at the same time. It is quite suitable for hospital with patient wards and large demand of hot water, especially buildings with large area of glazing curtain-wall. Field measurement was carried out during July 2018 at a major comprehensive hospital in Shenzhen, and the inner surface of the four-storey west-facing glazing curtain-wall reached over $45.6^{\circ} \mathrm{C}$ in the daytime. The year-round energy-saving potential is investigated by applying water-flow window to the curtain-wall through programme simulation, with a pre-validated FORTRAN programme. The results show that the year-round solar energy utilization rate can reach as high as $9.4 \%$, and the indoor thermal environment is better, compared with conventional window design. The preheated water can be used in wards for showering and help building energy conservation. Water-flow window has great potential for large-scale application within similar buildings.
\end{abstract}

\section{Introduction}

Water-flow window is unconventional building component that combines both active and passive solar designs. 1 With similar outlook as common window, water-flow window is composed of two parallel glazing panes acting as the front and back absorption plates of a solar thermal collector with flowing water in the middle.

Positioned in external walls as building transparent envelop, this system works as an advanced window device capable of reducing indoor solar heat gain. Meanwhile, the solar heat absorbed by the flowing water stream can be stored for domestic water preheating.

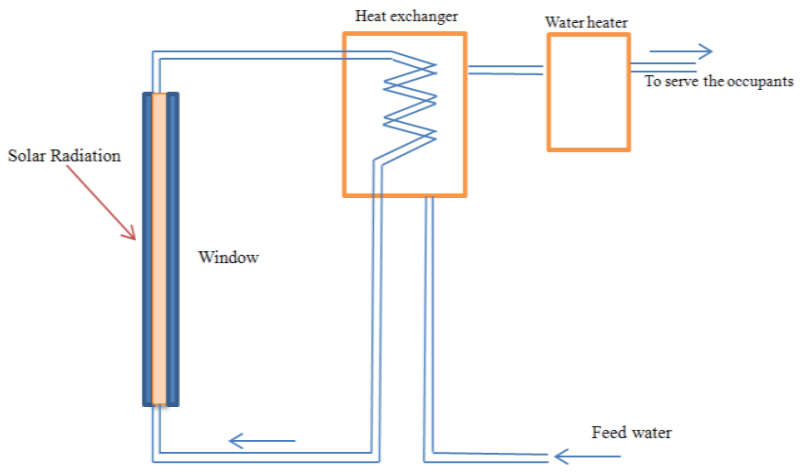

Fig. 1 is an illustration graph.

\footnotetext{
* Corresponding author: a-djh@163.com
}

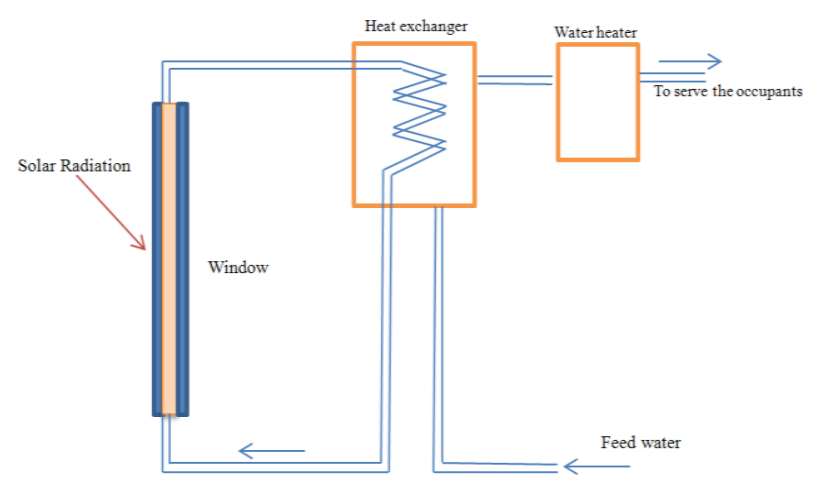

Fig. 1 Water-flow window as water preheating device

In sunny days, a part of the incident solar radiation is directly absorbed by the water layer. The portion absorbed by the adjacent glazing panes can be partly transferred to the water later on through convective heat transfer. The heat-carrying water in the window becomes hotter and lighter, flows upward to the water-to-water heat exchanger and preheats the cold feed water. When hot water is in need, this pre-heated water stream will be heated up to required temperature by gas/electrical heater. Such design can be utilized in most circumstances where hot water is in need. Considering the current climate change situation and energy shortage problem, there is great potential for extensive application of such system.

Hospitals usually consume great deal of hot water, especially comprehensive hospitals with impatient wards. By applying the water-flow window to building facade, 
the system may provide preheat water for patients and help hospital to save energy consumption and reduce electricity expenditure.

The application of water-flow window to the curtain wall of a comprehensive hospital in Shenzhen is numerically analyzed. The year-round solar collection efficiency and inner surface temperature are evaluated to predict the applicability and provide necessary information for future practice.

\section{Building information}

The hospital under investigation is a major comprehensive public hospital, with total floor area of $367,000 \mathrm{~m}^{2}$ and 2000 beds in operation. The outlook of the hospital is shown in Fig.2.

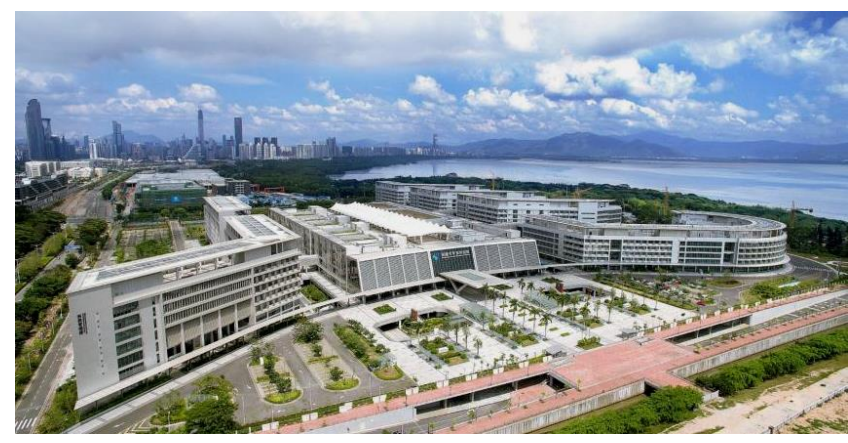

Fig. 2 The major comprehensive public hospital under investigation

In the hospital, the patients would complete the register, pay the bill and fetch the medicine within a large westfacing multi-function hall, with width of $115 \mathrm{~m}$ and height of $18 \mathrm{~m}$. The west side of the hall is a glazing curtain wall with main entrance in the middle, which is also composed with glass. The all-glazing construction would bring in excessive solar radiation than necessary for daylighting. In order to reduce the indoor heat gain and cooling load in summer, sunshade is applied outside of the curtain wall. However, the angle of the blade is fixed and cannot provide sun blocking constantly throughout the day. Therefore, it is often complained by both patients and hospital staff that the indoor thermal and visual environment being uncomfortable, especially in the afternoon with higher level of direct solar transmission.

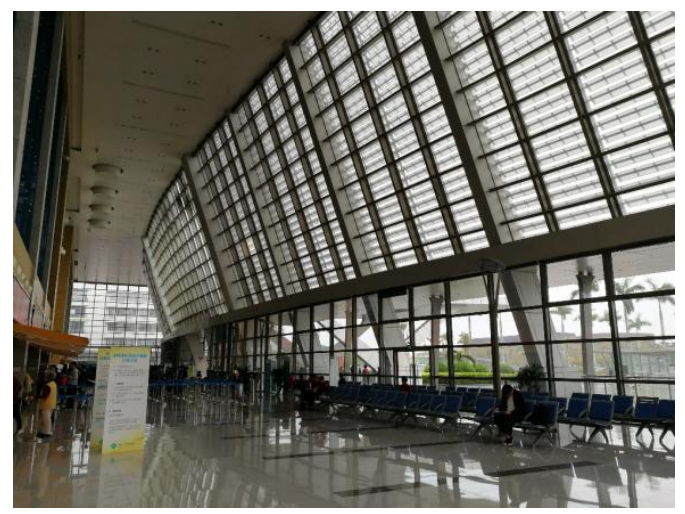

Fig. 3 The west-facing curtain wall of the multi-function hall

For creating more comfortable indoor environment and reducing energy consumption, building environment field measurement was carried out during July 2018. The inside and outside surface temperatures of the curtain wall were measured with infrared imaging with Testo890 instrument. The outside glazing surface temperature reached $45.6^{\circ} \mathrm{C}$ in a sunny afternoon. As for the inside surface, the peak value of $41.6^{\circ} \mathrm{C}$ occurred in the top area of middle part, without sunshade preventing direct solar transmission. For glazing panes with outdoor sunshade, the temperature is observed to be $5^{\circ} \mathrm{C}$ lower. $\mathrm{AC}$ system is equipped in the hall, and indoor temperature is preset as $26^{\circ} \mathrm{C}$ according to related national instruction. With $20^{\circ} \mathrm{C}$ temperature difference between glazing surface and indoor air, large amount of heat would enter the hall through radiative and convective heat transfer. This problem influences the thermal comfort of both patients and staff, as well as building energy consumption.

\section{Simulation model development}

In order to investigate the energy performance of waterflow window applied to this west-facing curtain wall, FORTRAN program is used. The model has already been validated through comparison between simulation results and experiments (with different orientations, sizes as well as glazing panes combination). [5]

In the physical model, the curtain wall is replaced with water-flow window, composed of two absorptive glazing panes and water-flow chamber in between. This combination proves to be able to explore the most amount of solar energy for sub-tropical climate. If the height difference between inlet and outlet of the waterflow window is too large, the static pressure of water would cause potential danger. So the water-flow window is designed to be equipped within a steel frame with dimensions of $2.4 \mathrm{~m}(\mathrm{H}) \times 1.6 \mathrm{~m}(\mathrm{~W})$. The circulating pipe is equipped within the frame, with diameter of $30 \mathrm{~mm}$. Double-pipe heat exchanger is located on the top of the window frame, with length of $1.6 \mathrm{~m}$ (the same as width of window frame) and outer/inner pipe diameter of $45 \mathrm{~mm} / 30 \mathrm{~mm}$. The water-flow window chamber is $30 \mathrm{~mm}$ thick. Water circulating between the chamber and the inner pipe of heat exchanger, and transfers heat absorbed within the chamber to the cold feed water (flows in the circular region between the inner pipe and outer pipe of the heat exchanger) at heat exchanger.

The west-oriented curtain wall is $115 \mathrm{~m}$ in width and $18 \mathrm{~m}$ in height, with area of $2070 \mathrm{~m}^{2}$. Considering the width of window frame, it would be appropriate for each water-flow window to occupy area of $1.9 \mathrm{~m}$ in width and $2.7 \mathrm{~m}$ in height. Considering the areas reserved for the entrance door, around 350 of water-flow window units can be equipped to replace the current curtain wall. For each water-flow window module, the flow rate of cold feed water is $0.005 \mathrm{~kg} / \mathrm{s}$, which proves to be suitable for the window size. The total cold feed water flow rate is 
therefore $1.75 \mathrm{~kg} / \mathrm{s}$, i.e. $6.3 \mathrm{~m}^{3} / \mathrm{h}$. The inlet water temperature is preset the same as the ambient environment. Considering the thermal insulation attached to the pipes of water network for the cities with cold winter, the inlet water temperature is preset to be $10^{\circ} \mathrm{C}$ if the ambient environment temperature is lower than $10^{\circ} \mathrm{C}$. The optical properties of the glazing pane used in this study are listed in Table. With TMY file of Shenzhen[5], the year-round performance of the water-flow window system can be numerically predicted.

Table 1 The optical properties of absorptive glazing

\begin{tabular}{|c|c|}
\hline Glazing Type & $\begin{array}{c}\text { Absorptive } \\
\text { glazing }\end{array}$ \\
\hline Thickness (m) & 12 \\
\hline Solar transmittance at normal incidence & 0.307 \\
\hline $\begin{array}{c}\text { Solar reflectance at normal incidence (front } \\
\text { side) }\end{array}$ & 0.048 \\
\hline $\begin{array}{c}\text { Solar reflectance at normal incidence (back } \\
\text { side) }\end{array}$ & 0.048 \\
\hline $\begin{array}{c}\text { Visible Transmittance at normal incidence } \\
\text { (front side) }\end{array}$ & 0.461 \\
\hline $\begin{array}{c}\text { Visible reflectance at normal incidence } \\
\text { (back side) }\end{array}$ & 0.054 \\
\hline $\begin{array}{c}\text { Visible reflectance at normal incidence } \\
\text { (bande }\end{array}$ & 0.054 \\
\hline
\end{tabular}

For better investigating the thermal performance of water-flow window, a comparative simulation is also completed (i.e. comparative case), where the window is composed with two similar absorptive glazing panes and sealed air in the middle. The dimensions, indoor and outdoor environment are preset the same as water-flow window.

\section{Results and analysis}

The year-round thermal performance of water-flow window (with dimensions of $2.4 \mathrm{~m} \times 1.6 \mathrm{~m}$ ), is shown as in Table 2. By dividing the total incident solar energy and water heat gain by $3.84 \mathrm{~m}^{2}$ (the area of the window), it is predicted that for the $1187 \mathrm{kWh}$ solar energy incident on every $1 \mathrm{~m}^{2}$ window around the year, the system could convert $9.39 \%$ of the energy, i.e. $111.5 \mathrm{kWh}$ into useful heat. The highest collector efficiency occurs in February, and is $10.18 \%$.

For the 350 water-flow window units (equipped as replacement of the current curtain wall), 39030kWh solar energy can be exploited to preheat water. The preheated water could be supplied to the inpatient wards for showering and so on. With the electricity-to-heat conversion efficiency of $95 \%$ and electricity fee of 0.68 yuan $/ \mathrm{kWh}$ in Shenzhen, the year-round electricity cost saving for water-heating devices is 26541yuan. Additional advantages are more comfortable indoor environment and lower electricity cost for AC system.
Table 2 Water-flow window performance in Shenzhen (westfacing window, $3.84 \mathrm{~m}^{2}$ )

\begin{tabular}{|c|c|c|c|}
\hline Month & $\begin{array}{c}\text { Incident } \\
\text { Solar Energy } \\
(\mathbf{k W h})\end{array}$ & $\begin{array}{l}\text { Water heat } \\
\text { gain }(\mathbf{k W h})\end{array}$ & $\begin{array}{l}\text { Thermal } \\
\text { efficiency } \\
(\%)\end{array}$ \\
\hline 1 & 341.30 & 32.81 & 9.61 \\
\hline 2 & 298.93 & 30.43 & 10.18 \\
\hline 3 & 323.81 & 28.00 & 8.65 \\
\hline 4 & 361.07 & 32.99 & 9.14 \\
\hline 5 & 397.89 & 36.83 & 9.26 \\
\hline 6 & 406.72 & 39.34 & 9.67 \\
\hline 7 & 467.90 & 41.46 & 8.86 \\
\hline 8 & 445.14 & 42.37 & 9.52 \\
\hline 9 & 382.07 & 34.20 & 8.95 \\
\hline 10 & 413.38 & 38.61 & 9.34 \\
\hline 11 & 367.66 & 36.32 & 9.88 \\
\hline 12 & 352.71 & 34.86 & 9.88 \\
\hline Sum & 4558.57 & 428.22 & 9.39 \\
\hline
\end{tabular}

For further illustrating the influence of the water-flow window to indoor thermal environment, typical summer week of $8^{\text {th }}-14^{\text {th }}$ July is chosen for discussion. The feed water temperatures at the inlet and outlet of the heat exchanger during this week are shown as in Fig.4, so does the glazing surface temperatures.

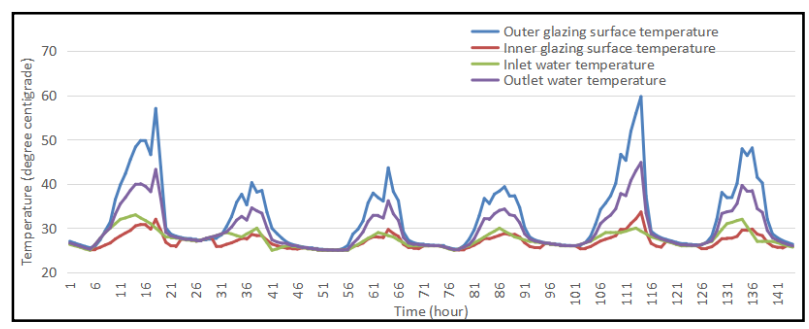

Fig. 4 The glazing surface temperature and water temperature variations during typical summer week

The inlet temperature of the feed water is preset the same as environment temperature, and is within the range of $25.0 \sim 33.0^{\circ} \mathrm{C}$. The outlet water temperature reached $44.8^{\circ} \mathrm{C}$ on the afternoon of 12 th July. The electricity consumption by water-heating device can be largely reduced thereby. Meanwhile, the peak value of inner glazing surface temperature of water-flow window occurs at the same time, which is $33.6^{\circ} \mathrm{C}$, much lower compared with the field measurement. This means the indoor heat gain through the large glazing curtain wall would be much smaller compared with current design. Also, the thermal comfort would be improved for the 
staff and inpatients. The AC system energy consumption can also be reduced tremendously.

Table 3 Water-flow window performance in Shenzhen (westfacing window, $3.84 \mathrm{~m}^{2}$ )

\begin{tabular}{|c|c|c|c|c|c|}
\hline $\begin{array}{c}\text { Tempera } \\
\text { ture }\end{array}$ & $\begin{array}{c}\text { Outdoor } \\
\text { temperat } \\
\text { ure }\left({ }^{\circ} \mathbf{C}\right)\end{array}$ & $\begin{array}{c}\text { Outer } \\
\text { glazing } \\
\text { surface } \\
\text { temperat } \\
\text { ure }\left({ }^{\circ} \mathbf{C}\right)\end{array}$ & $\begin{array}{c}\text { Inner } \\
\text { glazing } \\
\text { surface } \\
\text { temperat } \\
\text { ure }\left({ }^{\circ} \mathbf{C}\right)\end{array}$ & $\begin{array}{c}\text { Inlet } \\
\text { water } \\
\text { temperat } \\
\text { ure }\left({ }^{\circ} \mathbf{C}\right)\end{array}$ & $\begin{array}{c}\text { Outlet } \\
\text { water } \\
\text { temperat } \\
\text { ure }\left({ }^{\circ} \mathbf{C}\right)\end{array}$ \\
\hline $\begin{array}{c}\text { Maximu } \\
\text { m value }\end{array}$ & 33.0 & 59.7 & 33.6 & 33.0 & 44.8 \\
\hline $\begin{array}{c}\text { Minimum } \\
\text { value }\end{array}$ & 25.0 & 25.1 & 25.0 & 25.0 & 25.0 \\
\hline
\end{tabular}

As for the comparative case (double-layer of absorptive glazing panes with air sealed in the middle), the glazing surface temperature variations during the typical summer week are shown in Fig.5. The surface temperatures are higher in the daytime, with peak value of inner glazing surface temperature of $46.9^{\circ} \mathrm{C}$ appears on the afternoon of 12 th July, which means more indoor heat gain through the window.

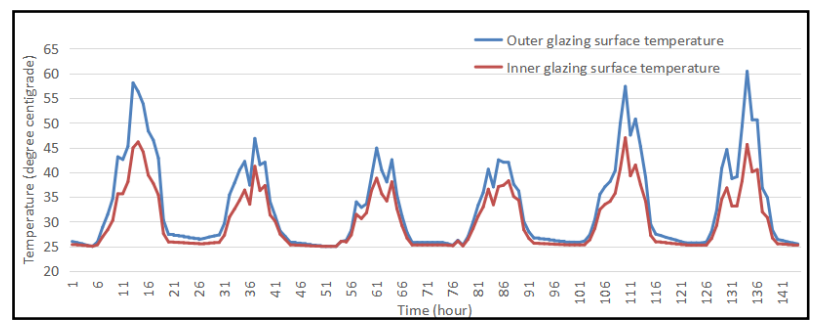

Fig. 5 The glazing surface temperature of comparative case during typical summer week

\section{Conclusion}

Field measurement was carried out during July 2018 to check the overheating problem of a large glazing curtain wall within a major comprehensive hospital in Shenzhen, China. The infrared images showed that the inner glazing surface temperature reached $45.6^{\circ} \mathrm{C}$ on a sunny afternoon. The heat transfer between the glazing and indoor air would cause tremendously cooling load for the AC system and discomfort for the indoor hospital staff and patients.

In order to solve this problem, water-flow window is introduced and applied to the west-facing curtain wall. By filling water within the double glazing panes and connect the cavity with a double-pipe heat exchanger, cold feed water can be preheat by two means: to absorb incident solar radiation directly, and convective heat gain from adjacent glazing panes. The purpose is to reduce indoor cooling load as well as to help save electricity consumption by water-heating devices. Through simulation, the water-flow window proves to be able to convert $9.4 \%$ incident solar energy into useful heat throughout the year. The inner glazing surface temperature remains below $34^{\circ} \mathrm{C}$ during typical summer week. A comparative case is also investigated where window is composed of double absorptive glazing panes. The inner glazing surface temperature reached $46.9^{\circ} \mathrm{C}$, which is much higher compared with the water-flow window case.

With water-flow window, the pre-heated water can be used in wards and has great potential for large-scale application for similar buildings. Considering the current climate change situation and energy emergency problem, it would be a general trend to explore more and more building components to realize solar energy utilization. Both architectures and engineers could be more creative for energy conservation and renewable energy utilization in buildings.

\section{Acknowledgments}

The authors are grateful for the financial support from the State Key Laboratory of Subtropical Building (Grant No. 2018ZB05) and Shenzhen University (New teachers' scientific research project, Grant No. 2018070).

\section{References}

1. Tin-tai Chow, Chunying Li, Zhang Lin, Innovative solar windows for cooling-demand climate, Solar Energy Materials and Solar Cells 94 (2), pp.212220. (2010)

2. Tin-Tai Chow, Chunying Li, Zhang Lin, Thermal characteristics of water-flow double-pane window, International Journal of Thermal Sciences 50 (2), pp. 140-148. (2011)

3. Tin-Tai Chow, Chunying Li, Zhang Lin, The function of solar absorbing window as water-heating device, Building and Environment 46 (4), pp. 955960. (2011)

4. T.T. Chow, Yuanli Lyu, Effect of design configurations on water flow window performance, Solar Energy, 155, pp. 354-362. (2017)

5. Yuan Li Lyu, Tin Tai Chow, Evaluation of Influence of Header Design on Water Flow Characteristics in Window Cavity with CFD, Energy Procedia, Volume 78, pp. 97-102. (2015)

6. Chunying Li, Performance evaluation of water-flow window glazing, $\mathrm{PhD}$ thesis, City University of Hong Kong, Hong Kong, China. (2012)

7. http://apps1.eere.energy.gov/buildings/energyplus/cf m/weather_data.cfm 